ARTICLE

DOI: $10.1057 /$ s41599-018-0137-1

\title{
Regional elections in Russia: instruments of authoritarian legitimacy or instability?
}

\author{
Cameron Ross ${ }^{1}$
}

\begin{abstract}
This study examines three rounds of regional assembly and gubernatorial elections in Russia that took place in September 2015, 2016 and 2017. In particular, it examines the ways in which the regime has manipulated the elections to guarantee the victory of United Russia. The study shows that the Kremlin has adopted a new electoral strategy. Rather than engaging in the risky business of outright fraud during the vote count, which was an important factor in sparking mass protests against the regime, in the wake of the 2011 elections to the State Duma, the authorities have decided to concentrate their efforts on preventing opposition parties and candidates from registering for the elections. Whilst other forms of electoral malpractice have continued to be practiced, such as coercing or bribing voters to turn out and vote for United Russia, promoting "carousel voting" (multiple voting by groups of mobilised citizens), or ballot stuffing, much more focus has been paid in these elections on manipulating the registration process in favour of United Russia. As is clearly demonstrated, scores of opposition candidates and party lists, have been prevented from competing because of problems with their registration documents. However, whilst this strategy has helped United Russia win large majorities in all of the gubernatorial and assembly elections, it has also created lacklustre and predictable contests, and this in turn has led to a sharp decline in turnout, particularly in the gubernatorial elections. There is a real danger that these low levels of turnout may gradually erode the legitimacy of United Russia, embolden the opposition, and threaten the stability of the regime.
\end{abstract}

\footnotetext{
${ }^{1}$ University of Dundee, Dundee, Scotland, UK. Correspondence and requests for materials should be addressed to C.R. (email: c.z.ross@dundee.ac.uk)
} 


\section{Introduction}

$\mathrm{n}$ this study I examine the democratic integrity of the last three rounds of regional assembly and gubernatorial elections which were conducted in Russia on 13 September 2015, 18 September 2016 and 10 September 2017. In total 56 regional assembly elections and 46 gubernatorial elections were held over this period. ${ }^{1}$ In particular I focus on the ways in which the regime manipulated these elections to ensure victory for the Kremlin's "party of power", United Russia (UR). I demonstrate that, although there were less overt forms of electoral fraud committed by the regime on election-day in these elections, other types of electoral malpractice concerning the registration process have led to scores of opposition candidates being denied entry to the contests. Thus, I conclude that Russia may still be classified as an "electoral authoritarian regime" (Schedler, 2013; Ross 2011, 2014; White, 2017).

Electoral authoritarian regimes. Schedler (2013, p. 2) makes an important distinction between "electoral democracies", which uphold Dahl's basic prerequisites for democracy, and what he terms "electoral authoritarian regimes" where electoral rules are grossly violated. According to Schedler (Ibid), electoral authoritarian regimes hold regular elections which are, 'broadly inclusive (they are held under universal suffrage), minimally pluralistic (opposition parties are permitted to run), minimally competitive (parties and candidates outside the ruling coalition, while denied victory, are allowed to win votes and seats, minimally open (dissidence is not subject to massive, but often to selective and intermittent repression).' Elections in electoral authoritarian regimes however, are not minimally democratic, as 'governments subject them to manifold forms of authoritarian manipulation that violate the liberal-democratic principles of freedom, fairness, and integrity' (Ibid). Rulers in electoral authoritarian regimes, 'may place barriers on opposition parties' ability to campaign; generate a pro-government media bias; stack electoral commissions and courts with their supporters; or resort to stuffing ballot boxes and manipulating vote tabulations' (Donno, 2013, p. 704). All of these forms of electoral malpractice have been widely practiced in Russian regional elections (see Ross, 2011, 2014).

The Kremlin's new strategy. As Petrov (2012, p. 1) notes, following the mass protest demonstrations against the regime, in the wake of the highly fraudulent Duma elections of December 2011, the Kremlin adopted a new strategy towards controlling elections. Rather than engaging in the risky business of outright fraud during the vote count, which was an important factor in sparking mass protests against the regime, the authorities decided to concentrate their efforts on preventing opposition parties and candidates from registering for elections. According to the "Golos Election Monitoring Association", (hereafter, Golos), the 2015a-d election campaign 'reinforced an emerging trend... the shifting of emphasis in the application of administrative technologies from voting day to earlier stages of the electoral process (2015a-d, p. 1). As Schulmann (201, p. 2) notes, 'the main obstacle to competitive elections in Russia is still the participation barrier. Existing legislation favours "systemic" parties that are already in government and incumbents. The rule is: "Once you're in, we help you stay in."'

This study will therefore focus, in particular, on the ways in which the registration process has been used and abused by the authorities to ensure that opposition parties and candidates are prevented from competing in regional assembly and gubernatorial elections.

A key factor in the Kremlin's ability to manipulate elections and deny opposition parties and candidates from participation in the elections is its control over electoral commissions which in many regions are far from neutral (see Popova 2006; Baekken (2015); Harvey 2016; Jarabinský, 2015; Bader, 2017). According to Article 23.6 of the Federal Law No. 67, 12 June 2002, 'On the Basic Guarantees of Electoral Rights and the Right to Participate in a Referendum of Citizens of the Russian Federation', half of the members of the regional electoral commissions are appointed by regional governors and the other half by the regional assemblies, taking into consideration proposals of the Central Electoral Commission of the Russian Federation, political parties, municipalities, and the previous commissions. Article 23.5 further states that, the Central Electoral Commission has two quota places. Parties which are represented in the State Duma are provided with one quota, as are parties with representation in regional assemblies where the corresponding electoral commissions are formed. The chairs of the regional election commissions are elected at the first meeting of the commissions on the recommendation of the Central Electoral Commission (Federal Law, No. 67, 12 June 2002).

United Russia which dominates regional assemblies and executive bodies has been able to use its domination of the membership of the commissions to bolster its electoral support. Thus, for example, as Bader has demonstrated in his study of the 2016 Duma elections - in those commissions chaired by members of United Russia, the reported levels of turnout and support for UR were much higher than in those chaired by members of other parties (Bader, 2017, p. 448).

The Kremlin has also been able to maintain its dominance in the regions by manipulating election and party laws. Indeed, since Putin came to power in 2000 , no election in Russia has been held according to the same rules as its predecessor and there have been scores of amendments to election and party legislation in the regions. As Hutcheson notes, over the period 2003-16, the State Duma law was amended 40 times; the Law on Political Parties 36 times, and the Law on Fundamental Guarantees of Electoral Rights, 78 times (2017, pp. 389-390).

Changes to the legislation on parties. In the wake of the mass protest demonstrations against the regime, radical changes to electoral and party registration laws were adopted in Spring 2012, which made it much easier for parties to register and participate in elections. According to these amendments the number of party members required for registration was drastically reduced from 40,000 to just 500! (Federal Law 28, 2 April, 2012). As a result of this new legislation the number of parties rose sharply from 7 in 2011 to 74 in September 2015. This has led to the creation of a weak and fragmented opposition (see Ross, 2014). In 201548 parties took part in the regional elections, in 2016 there were 55 parties and in 2017, 28.

Legislation on electoral registration. An important development which impacted on the registration process took place in 2009 when electoral deposits were abolished, which meant that parties could only register for elections by submitting nomination signatures (in most regions the number required was $2 \%$ of the regional electorate). According to amendments made to Federal Law, No. 67 (Article 38.24), a candidate's nomination was rejected if they did not submit enough signatures or if $10 \%$ of their signatures were found to be invalid.

However, in the aftermath of the mass demonstrations which erupted in 2011, positive changes were made to electoral legislation in 2012 which stipulated that party list candidates no longer needed to submit nomination signatures to register for elections, and the maximum number of signatures required by 
independent candidates was lowered from 2 to $0.5 \%$ (see, Federal Law No. 41, 2 May 2012). These developments made it easier for opposition parties to pass the registration hurdles. In the first two rounds of regional elections to be conducted under the new rules, in October 2012 and September 2013, there was a dramatic reduction in the number of party lists which were prevented from competing. The average number of registered party lists per region rose from 13.2 in 2012 to 17.2 in September 2013, the highest on record (Kynev and Lyubarev, 2016, p. 18).

However, 'the liberalisation of the electoral rules soon came to an end as the mass protests movement against the regime lost momentum and the Putin regime began to feel more secure' (see Korgunyuk et al. 2017:). Thus, in 2014 new legislation was adopted which reversed many of the positive changes enacted in 2012 (see Borisov et al. 2015). Thus, for example, in May 2014 the requirement of party list candidates to collect nomination signatures was reinstated (although the percentage of signatures required was lowered from 2 to $0.5 \%$ of the electorate). At the same time, the number of signatures demanded for candidates in the single mandate elections was raised from 0.5 to $3 \%$ of the electorate (Federal Law, No. 95, 5 May 2014). One positive feature adopted by Federal Law No. 95 (5 May 2014), reduced the maximum allowable electoral threshold for regional elections from seven to five per cent which gave smaller parties a better chance to win seats (see Korgunyuk et al. 2017).

However, the registration process is not a level playing field. Parties which hold seats in the Duma or receive $3 \%$ of the votes in elections to the State Duma are exempt from gathering signatures (Ibid). This meant that the four Duma parliamentary parties UR, CPRF, LDPR, and JR qualified for the 2015-2017 elections by default. The non-parliamentary opposition party Yabloko also qualified for the elections held between 2011 and 2016: as it won $3.4 \%$ of the votes in the Duma elections in 2011 it did not need to gather signatures to register.

In addition, parties which hold seats in, or win $3 \%$ of the votes in regional assemblies, or $0.5 \%$ of the total number of seats in a region's municipal councils, are exempt from submitting signatures in those particular regions, and this has allowed a number of opposition parties, to compete in a few regions without submitting signatures. Thus, for example, Yabloko failed to gain the required $3 \%$ of the votes in the 2016 Duma elections but was nonetheless able to compete in some regions in 2017 without submitting nomination signatures as it held the required number of seats in regional/municipal parliaments.

The reinstatement of the need to gather nomination signatures in 2014 resulted in a sharp fall in the average number of party lists which were registered for regional assembly elections, from 17.2 in 2013 to 7.8 in 2015, 6.9 in 2016 and 7.7 in 2017 (Kynev, Lyubarev and Maksimov, 2017a, b, p. 5).

\section{Parties denied registration in regional assemblies}

Scores of opposition candidates and party lists have been unable to register for elections because the electoral commissions have declared their signatures invalid. Thus, for example, candidates were denied registration because they wrote the date or signed their name in the wrong place on their nomination forms, or because of other equally petty mistakes made by the collectors of the signatures (see Ross, 2011, 2014).

Candidates have also been denied access to elections because of "problems" with the information they provided with regard to their education, income, and other personal details. Some candidates have failed to be registered because the information they provided on their documents did not tally with information (sometimes of doubtful authenticity) held in the data-bases of the electoral commissions and the Federal Migration Service. Thus, for example, in 2015 an absurd example was found in municipal elections in Rostov Region. According to Golos, the Novocherkassk City Court denied the registration of three members of the Communist Party. The grounds for their exclusion was 'because the diacritical marks above the letter "ë" in the candidates' documents contained a reference to a "Budënnovskaya Street," but the official name of the street is "Budennovskaya" (2015c, pp. $2-3$ ).' Because of this petty mistake (not a deliberate act of falsification) the candidates were prevented from standing in the election.

It would also appear that when it comes to registration, there is one rule for United Russia and members of the so-called "systemic opposition" (those opposition parties which hold seats in the State Duma), and another set of rules for members of the non-systemic opposition (those parties which are not represented in the Duma). In the 2015-17 rounds of regional elections the systemic opposition included, the Communist Party of the Russian Federation (CPRF), Just Russia (JR), and the Liberal Democratic Party of Russia (LDPR). Members of the "non-systemic opposition" will come under much greater scrutiny than members of the loyal "systemic opposition" when they submit their registration documents to the electoral commissions. Overall $27.3 \%$ of the party lists nominated for the 2015-2017 rounds of regional assembly elections were denied registration (all the data on registration is calculated from Kynev et al. 2015, 2017a, b, 2016, and the Russian Central Electoral Commission website, http://www.cikrf.ru). In 2015 the figure was $38.3 \%$ and there were four regions where over $50 \%$ of the party lists were prevented from competing: Magadan (64.7\%), Chelyabinsk (54.5\%), Novosibirsk (53.3\%) and Voronezh (50.0\%). In 2016, 24.3\% of party lists were prevented from competing. In this round of elections there were three regions where over half the party lists were rejected. Orel (55.5\%), Leningrad (54.5\%) and Novgorod (50\%). In 2017 the total numbers of party lists that were rejected was $19.3 \%$. Of the 57 party lists which were nominated (in total across all regions), 38 had electoral privileges and did not need to gather signatures and 36 of these party lists were registered, whilst just 10 of the 19 party lists without privileges were able to compete. The highest number of party lists which were rejected in 2017 was in Krasnodar Krai $(37.5 \%)$ followed by Udmurtia $(33.0 \%)$ and North Ossetia (30.7\%) (Kynev et al. 2017a, b, pp. 5-6).

When we examine which parties have been denied registration we find that, in the vast majority of cases, they were members of the "non-systemic opposition". None of United Russia's party lists were denied entry to the 2015-2017 elections and the three other systemic opposition parties (CPRF, LDPR and JR) also fared much better than the non-systemic parties.

Thus, for example, in 2015 all 56 of the nominated party lists who had privileges were able to register whilst of the 85 party lists which had to collect signatures $30(65 \%)$ failed to pass the registration stage (www.cikrf.ru).

Likewise, in 2016 the parties which did not need to collect signatures were able to register almost all of their candidates (United Russia 99.4\%, the CPRF 99.1\%, the LDPR 99.0\%, JR 98.3\%; Yabloko 96.3\%), however, the figures for the non-systemic opposition parties which were required to gather signatures was much lower. Patriots of Russia was able to register $82.1 \%$ of its candidates; the Party of Growth 74.3\% Rodina 41.9\%; Pensioners for Justice, 59.4\% (www.cikrf.ru).

In 2017, 443 of UR's 445 candidates were registered, the CPRF registered 312 of its 326 candidates, LDPR was successful in registering 310 of its 318 candidates and Just Russia registered 304 of its 313 candidates. In comparison the liberal opposition party Yabloko was only able to register 42 of its 65 candidates, and none of the candidates from the liberal coalition PARNAS, were able to take part in the elections (www.cikrf.ru). In 2017 
$100 \%$ of the parties which had to gather signatures, were denied registration in Udmurtia, as were $50 \%$ of the parties in Krasnodar and $63 \%$ in Sakhalin (Kynev et al. 2017a, b, p. 6).

Elections in the single member districts. Up until November 2013, in a majority of regions, half of the deputies to regional assemblies were elected in party list elections and half in single mandate races. However, amendments to Federal Law No. 303, 2 November 2013, lowered the minimum percentage of proportional representation seats from 50 to $25 \%$, and the requirement to use proportional representation was lifted completely for Moscow and St. Petersburg.

Table 1 shows that a total of $20.7 \%$ of the candidates who stood in the single member district elections were denied registration in the 2015 elections, $19 \%$ in 2016 and $8.0 \%$ in 2017. However, for those parties with privileges (who did not need to submit nomination signatures) the corresponding figures were just 2.1, 3.0 and $1 \%$. In sharp contrast, if we examine the opposition candidates who were without privileges we see that the number of those who were denied registration was much higher comprising; $89.4 \%$ in $2015,86.0 \%$ in 2016 and $57.0 \%$ in 2017 . Independent, candidates also fared badly with $61.9 \%$ denied registration in $2015,63 \%$ in 2016 and $53 \%$ in 2017 . In 2016 , not a single party that had to collect signatures was registered in 15 of the 34 regional elections. Whilst in some cases parties and candidates have correctly been denied access to the elections because they failed to comply with the rules governing the nomination and registration process, in many others cases they have deliberately

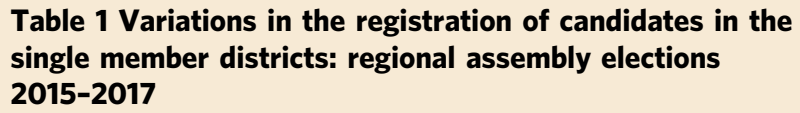

\begin{tabular}{|c|c|c|c|c|}
\hline Election & Total & $\begin{array}{l}\text { With } \\
\text { privileges } \\
\text { (no need to } \\
\text { gather } \\
\text { signatures) }\end{array}$ & $\begin{array}{l}\text { Without } \\
\text { privileges } \\
\text { (required to } \\
\text { gather } \\
\text { signatures) }\end{array}$ & $\begin{array}{l}\text { Independent } \\
\text { candidates }\end{array}$ \\
\hline \multicolumn{5}{|l|}{2015} \\
\hline Nominated & 1302 & 956 & 133 & 213 \\
\hline Registered & 1032 & 935 & 14 & 83 \\
\hline $\begin{array}{l}\% \text { Filtered out } \\
2016\end{array}$ & $20.7 \%$ & $2.1 \%$ & $89.4 \%$ & $61.0 \%$ \\
\hline Nominated & 5272 & 4019 & 571 & 682 \\
\hline Registered & 4282 & 3948 & 80 & 254 \\
\hline $\begin{array}{l}\text { \% Filtered Out } \\
2017\end{array}$ & $19.0 \%$ & $3.0 \%$ & $86.0 \%$ & $63.0 \%$ \\
\hline Nominated & 627 & 549 & 14 & 64 \\
\hline Registered & 577 & 541 & 6 & 30 \\
\hline$\%$ Filtered Out & $8.0 \%$ & $1.0 \%$ & $57.0 \%$ & $53.0 \%$ \\
\hline
\end{tabular}

Source: Compiled from data in Kynev et al. 2015, 2016 and 2017a, b, and Central Electoral Commission Website, http://www.cikrf.ru been targeted by the Kremlin which has used its control over the electoral commissions to prevent them from participation in the elections.

As noted above, in virtually all of the cases, the reason for candidates being denied registration was due to problems with the documentation relating to their nomination signatures. In 2015 one of the fiercest attacks was against The People's Freedom Party (PARNAS), which was made up of a coalition of liberal parties. The Coalition, put forward candidates in four regionsKaluga, Kostroma, Magadan and Novosibirsk. However, it only succeeded in registering them in Kostroma, after an initial decision to ban them in that region was overturned on appeal (Litvinova, 2015, p. 1).

According to Golos, in 2016 the main attack was on two of the opposition liberal parties, PARNAS, and Civic Initiatives, in addition to a group of patriotic parties, Rodina (Motherland), Party of the Great Fatherland, Renaissance of Russia and National Security of Russia. Rodina lost half of its party lists in the registration process. With regard to PARNAS and Renaissance of Russia, initially all of their lists were rejected and it was only after the intervention of the Central Electoral Commission that both parties were allowed to register one of their lists (the Renaissance of Russia party later withdrew from the elections). None of the party lists of Civil Initiative, National Security of Russia and the Party of the Great Patriotic War were registered (Golos, 2016, p. 6).

In 2017 the four Duma parties (United Russia, CPRF, LDPR and JR) passed the registration process in all six electoral campaigns whilst members of the non-systemic opposition fared much worse. Thus, for example, in the Republic of North OssetiaAlania, Yabloko, the Russian All-People's Union, the Veterans Party of Russia and the Russian Socialist Party failed the registration process. In the Republic of Udmurtia, three of the nine nominated parties were rejected (PARNAS, Party of Social Reform and Party of Russia's Rebirth). In Krasnodar Kray, Yabloko and Rodina were denied certification, and the Great Fatherland Party was denied registration. Finally, Party Action was not registered in the Sakhalin region (Golos, 2017a, b, p. 3).

\section{Results of the regional assembly elections}

In 2015 United Russia won an average of $59.1 \%$ of the party list votes, $58.0 \%$ in 2016 and $62.2 \%$ in 2017 (see Table 2). The Communists came in second in 2015 and 2017, and they were third in 2016, but they were a long way behind UR with just $12.3-14.1 \%$ of the votes, followed by the LDPR $(8.3-15.8 \%$ of the votes) and Just Russia (3.6-9.8\%).

However, UR's percentage of party list seats was much higher than its percentage of votes- it won an average of $80.4 \%$ of the seats in $2015,74.6 \%$ in 2016 and $77.7 \%$ in 2017 . In sharp contrast, for the other parties, their percentage of party list seats was lower than their percentage of votes (see Table 2). This is due to the fact that the type of proportional system employed in most of the regions (primarily, "Imperiali" and "Tyumen") favours dominant parties (see Golosov, 2014). Overall, the four parliamentary

Table 2 Average percentage of votes and party list seats in regional assembly elections: parliamentary parties, 2015-2017

\begin{tabular}{|c|c|c|c|c|c|c|c|c|}
\hline Date & Votes & Seats & Votes & Seats & Votes & Seats & Votes & Seats \\
\hline Sept. 2015 & $59.1 \%$ & $80.4 \%$ & $12.3 \%$ & $8.4 \%$ & $9.9 \%$ & $4.3 \%$ & $9.8 \%$ & $5.2 \%$ \\
\hline Sept. 2017 & $62.2 \%$ & $77.7 \%$ & $12.8 \%$ & $8.4 \%$ & $8.3 \%$ & $3.6 \%$ & $6.0 \%$ & $3.0 \%$ \\
\hline
\end{tabular}


Table 3 Distribution of party list and single mandate seats in regional assemblies 2015, 2016 and 2017

\begin{tabular}{|c|c|c|c|c|c|c|c|c|}
\hline & \multicolumn{2}{|c|}{ United Russia } & \multicolumn{2}{|l|}{ CPRF } & \multicolumn{2}{|l|}{ LDPR } & \multicolumn{2}{|l|}{$\mathbf{J R}$} \\
\hline & $\mathbf{P L}$ & SMD & PL & SMD & PL & SMD & PL & SMD \\
\hline 2015 (11 elections) & 158 & 213 & 32 & 8 & 20 & 0 & 21 & 2 \\
\hline 2016 (39 elections) & 569 & 747 & 150 & 8 & 146 & 7 & 88 & 11 \\
\hline $2017^{\star}$ (6 elections) & 139 & 101 & 20 & 4 & 9 & 1 & 10 & 2 \\
\hline Total & 866 & 1061 & 202 & 20 & 175 & 8 & 119 & 15 \\
\hline
\end{tabular}

Table 4 Nomination and registration of gubernatorial candidates 2015-2017

\begin{tabular}{|c|c|c|c|c|c|}
\hline $\begin{array}{l}\text { Date of } \\
\text { election }\end{array}$ & $\begin{array}{l}\text { No. of } \\
\text { regions }\end{array}$ & $\begin{array}{l}\text { No. of candidates } \\
\text { nominated }\end{array}$ & $\begin{array}{l}\text { Average no. of candidates in } \\
\text { each region }\end{array}$ & $\begin{array}{l}\text { No. }(\%) \text { of candidates } \\
\text { registered }\end{array}$ & $\begin{array}{l}\text { No. }(\%) \text { of candidates } \\
\text { denied registration }\end{array}$ \\
\hline 13 Sept. 2015 & 21 & 142 & 6.7 & $98(69.0)$ & $44(31.0)$ \\
\hline 18 Sept. 2016 & 7 & 41 & 5.8 & $32(78.0)$ & $9(22.0)$ \\
\hline 10 Sept. 2017 & 16 & 105 & 4.5 & $72(68.5)$ & 33 (31.5) \\
\hline Total & 44 & 288 & 5.6 & $202(70.1)$ & $86(29.9)$ \\
\hline
\end{tabular}

Source: Calculated by the author from data on the Central Electoral Commission, http://www.cikrf.ru/analog/vib_100917/kand_vdl.html

parties (UR, CPRF, LDPR and JR) won a total of $98.3 \%$ of the party list seats in $2015,98.5 \%$ in 2016 and $92.7 \%$ in 2017 (www. cikf.ru).

Turning to the single mandate races, United Russia won even more seats in these elections than in the party list contests. As can be seen in Table 3, UR swept the board in the single mandate races, winning a total of 1061 seats, which is higher than the 866 seats it won in the party list elections. In sharp contrast the other members of the systemic opposition all fared much worse in the single mandate races than they did in the party list contests.

It is important to note that these victories for UR came at a time when the country was in the midst of a major economic recession. However, the crisis in Ukraine and Russia's annexation of Crimea in 2014 strengthened support for the regime and fundamentally weakened candidates from the non-systemic opposition, particularly the liberal-democratic wing which came out publicly against the annexation. According to polls conducted by the Levada Centre, President Putin's approval ratings shot up from $65 \%$ in January 2014 to $84 \%$ in September 2015, and it was $82 \%$ in September 2016, and $83 \%$ at the time of the most recent elections in September 2017 (Levada Centre, http://www.levada. $\mathrm{ru}$ /indeksy). However, we should also note that these victories were accompanied by falling levels in turnout which in 2017 was just $26 \%$ in Sakhalin and $34.5 \%$ in the Udmurt Republic. As discussed below, low turnout may gradually undermine the legitimacy of the regime.

\section{Electoral rules governing gubernatorial elections}

The mass protests following the December 2011 elections spurred the Kremlin into taking action to strengthen the regime's legitimacy. New legislation was adopted in 2012 which reintroduced direct elections for regional governors. [[From 2005 until 2012 the president was granted the right to appoint the governors subject to the approval of the regional legislatures.]] However, legislation adopted in May 2012 introduced a controversial new procedure regarding the registration of candidates. In order to register for gubernatorial elections, candidates must first pass a 'municipal filter' by gaining the support of a percentage of the deputies and heads of municipalities in their regions. The mandatory percentage varies from region to region, from $5-10 \%$, and candidates must also obtain a "territorial quota" (support from deputies who hold municipal seats in a mixture of councils which belong to different levels of administrative jurisdiction).

The municipal filter has enabled the Kremlin to squeeze out popular opposition candidates from the ballot and control who will be able to stand in the elections. Thus, for example, an average of $29.9 \%$ of the gubernatorial candidates who were nominated for the 2015-2017 elections, did not make it through to the ballot. In 2015 the figure was $31.0 \%$, in $2016,22.0 \%$ and in 2017, 31.5\% (see Table 4).

UR control over the collection of signatures. The most serious barrier to the registration of opposition candidates, is the simple fact that the vast majority of local councils are dominated by members of United Russia and this makes it extremely difficult for candidates not approved by the party to gather the required signatures to be registered.

As Golos (2015c, p. 2) reports, it is common practice for regional governments to instruct urban and rural municipal councils to collect their signatures centrally and then assign them to UR's choice of candidates, which makes it impossible for opposition candidates to enter the race without the support of the "party of power". Thus, for example, Vasily Pronichev (a member of the opposition party, Patriots of Russia) who stood in the 2015a-d election in Irkutsk, was able to collect the necessary number of signatures, but because these were not from a sufficient number of municipalities, he did not fulfil the territorial quota and thus, was not able to submit them for registration. At a press conference on 31 July 2015a-d, Pronichev noted that the passage through the 'filter process' was controlled by officials from the regional and local administrations and notaries who blocked his nomination (Golos, 2015b, p. 8). Sergey Zhuravsky, a candidate from the party Rodina who sought to compete in the Kaliningrad region, in 2015, wrote a letter to the Regional Electoral Commission where he noted that he was unable to submit his documents because the deputies who supported his nomination were too scared to disclose their names. They feared that they may be subjected to persecution for daring to support his candidacy. Many of them were afraid of being laid off from 
work, as they are dependent for employment on the regional administration (Ibid).

Often opposition candidates are faced with the absurd task of having to turn to United Russia to ask for help in collecting signatures. Thus, for example, in 2015 gubernatorial candidates from the systemic opposition parties, LDPR, JR and CPRF were forced to appeal to the Mari-El branch of United Russia for help in collecting their signatures and they were eventually registered (Ibid). In contrast, Sergey Gulyaev, who is a member of the nonsystemic opposition party, PARNAS, failed in his bid to register in Leningrad. In this case UR declined his appeals for help in collecting signatures (Ibid).

In 2016 Vadim Solov'ev, who was a senior lawyer for the Communist Party, and an experienced campaigner, failed in his bid to register for the Gubernatorial Election in Tver Region. He managed to collect the correct number of signatures (58), but without the help of UR it was impossible for him to meet the stringent "territorial quota" which required that he collect signatures from three quarters of the municipal and city districts. He collected signatures from 27 districts but to be registered he needed signatures from 33 districts which was impossible without UR's support (Kynev et al. 2016, p. 16).

In some cases, a candidate may be promised signatures by deputies who have already given them to someone else. According to Anna Cherepanova, a candidate from Yabloko who was denied registration for the 2017 election in Novgorod Region, "several deputies who insisted that they had not already given anyone a signature, agreed to give them in support of my candidacy. Then it turned out that the head of the rural settlement had already certified their signatures in favour of another candidate" (Golos, 2017a, p. 5).

According to the authorities, the municipal filter is ostensibly there to prevent candidates who have little support in the regions from standing in the elections. However, as Golos has shown, the filter process has not succeeded in screening out unpopular candidates and parties (2017a, p. 2). Nor has it prevented the registration of "spoiler" candidates, who are supported by the Kremlin, but have no intention of taking up their posts. At the same time, in each round of elections there are a number of senior opposition politicians who are denied participation in the elections even although (or because) they command potentially high levels of electoral support. Thus, for example, according to Pertsev, in 13 of the 16 gubernatorial elections conducted in 2017, 'only obscure candidates were allowed to challenge the incumbent governors. Candidates who posed even the slightest risk to the establishment were kept off the ballot' (2017a, p. 1). The Chair of the Russian Central Electoral Commission, Ella Pamfilova was forced to admit, that the filter mechanism was "cynically" exploited by regional elites in 2017 to keep the Communist candidate, Vyacheslav Markhaev, off the ballot in the gubernatorial election in the Republic of Buryatia (Schreck, 2017).

All of these factors have led to a situation whereby United Russia (under the command of the Kremlin) decides which opposition candidates will be allowed to enter the registration stage and ultimately who will compete against them. As Ryzhkov notes, 'By eliminating the strongest rivals at the registration stage of elections, the authorities nip all competition in the bud. Elections lose all meaning and become nothing but a referendum on support for the incumbent governor' (2014, p. 2). However, one negative feature of removing popular candidates from elections is that it leads to lower turnout, which in turn undermines regime legitimacy. Thus, for example, in every gubernatorial election in 2017, except for that in Sverdlovsk, the turnout was lower than in the previous election (Kynev et al. 2017a, p. 5).
Results of gubernatorial elections. Not surprisingly, United Russia won 19 of the 21 gubernatorial elections in 2015 (UR sanctioned the victory of the LDPR candidate in Smolensk). UR also won all 7 of the elections in 2016 (in Tula an independent candidate was supported by UR) and all 16 elections in 2017. There has been only one defeat for UR which was in Irkutsk in 2015 where a member of the CPRF won the election in the second round.

In 2015 support for UR varied from $50.6 \%$ in Amur region to $94.4 \%$ in Tatarstan, and $96.7 \%$ in Kemerovo Oblast. In 2016 the lowest level of support for the winner was 54.3\% in Zabaikalsky Krai and Ulyanovsk Oblast, and the highest was in Chechnya where Kadyrov was elected with a massive $96.4 \%$, and there was another very high level of support for Sholban who won $85.6 \%$ of the votes in Tuva. In 2017 victories for UR candidates were also very high. In 7 of the 16 regions UR won over $80 \%$ of the votes and in one other region (Yaroslavl') it won 79.3\%. The highest levels of support were in Mordovia (89.1\%), Mari-El (88.2\%), and Buryatia (87.4\%). The lowest levels of support were in Tomsk (60.5\%), Sverdlovsk (62.1\%) and Kirov (64.0\%) (www.cikrf.ru).

\section{Municipal elections in $\mathbf{2 0 1 7}$}

In a surprise result, opposition candidates scored important victories in the 2017 municipal elections in Moscow. Out of a total of 1502 deputies elected to the district councils 266 , or roughly $18 \%$ were won by candidates from the Alliance of United Democrats headed by Dmitry Gudkov. These municipal elections were a key target of the Alliance, as success here would allow them to pass the municipal filter and gain access to the Moscow Mayoral Election in March 2018. However, whilst they scored a number of surprising victories, including winning all the seats in the Gagarin district where President Putin cast his vote, they did not win enough seats in enough districts to overcome the municipal filter. Opposition candidates won seats in 66 district councils but to pass the filter they need representation in 110 municipalities (Davydov, 2017, p. 1). Nonetheless, this was clearly an important symbolic victory for the liberal opposition. In 2012, there were only three districts in Moscow where United Russia did not command a majority, now there are 28. Furthermore, a number of local councils have no United Russia representation at all (Ibid, p. 2).

It would appear that the Moscow City Government's strategy of suppressing turnout, which was just 15\%, backfired. As Pertsev notes, 'an active reform-minded minority turned out to vote on September 10, while a discontented passive majority stayed at home' (2017, p. 1). Those who voted were not the expected, 'state employees, housing and communal services workers, military and pensioners' (Schulmann, 2017, p. 2) who are normally mobilised by the authorities, but rather, as Davydov notes, 'those citizens whose votes had been solicited by youthful, charismatic candidates from the liberal opposition' (Ibid). However, it is important to stress that despite the setback, UR still manged to win over $75 \%$ of the seats.

\section{Conclusion}

As this study has demonstrated there is no level playing field for elections in the vast majority of Russian regions. The electoral registration process is far from free and fair for both regional assembly and gubernatorial elections. Popular parties have been ousted from regional contests because of minor infringements in their registration documents, problems with the verification of their registration signatures and/or electoral deposits and because of petty errors in their documentation. As Baekken notes, it is not unusual for penalties to be imposed for these types of electoral infringements in other countries, but in most cases a fine would 
be imposed. In Russia, 'the principle of proportional punishment seems to have been neglected', here 'minor infringements can lead to candidates being deprived of their constitutional right to stand for elections' (2015, p. 65). In gubernatorial elections, opposition candidates have been faced with the near impossible task of passing the municipal filter as United Russia holds the vast majority of municipal seats.

Elections in semi-authoritarian regimes. As Kaya and Bernhard note there are two opposing perspectives on the impact of elections on the stability and longevity of authoritarian regimes, the first of which they label "electoral authoritarianism" and the second "democratization by elections" (2013, p. 735). According to the first perspective, elections play a major positive role in stabilising and bolstering authoritarian regimes. In contrast, according to scholars who support the second perspective, elections are risky for authoritarian rules, as once undertaken they 'can establish a path to incremental democratization' (Ibid).

On the positive side of the equation, Harvey notes, 'multi-party elections allow authoritarian rulers to co-opt the opposition, to channel their demands into the structured setting of the legislature, to gather information, and deter elite defections' (2016, p. 106). Elections also help to bolster the legitimacy of authoritarian rulers. In addition, the results of multiparty elections help the regime to identify their bases of support and opposition. This is particularly important in large multi-national countries, such as the Russian Federation. Moreover, as Ghandi and Lust-Okar observe, by holding elections and setting rules regarding the legal eligibility of candidates and parties, dictators create divided structures of contestation composed of outsiders who are not allowed to compete and insiders who become more invested in the regime' (2009, p. 405).

Simpser (2013, p. 1) also points so some of the advantages which accrue to an authoritarian regime when it engages in electoral fraud. He challenges the idea that electoral manipulation is primarily 'an election-winning phenomenon'. As he demonstrates, electoral manipulation is often carried out in circumstances in which the incumbent authorities would have won the election without resorting to fraud. Moreover, many acts of manipulation are not concealed from public view.

According to Simpser, this brazen manipulation, serves the following functions: 'it discourages opposition voters from turning out to vote or protest; convinces bureaucrats to remain loyal to government; deters political elites from opposing the ruling party and increases the manipulator's post-electoral bargaining power', and finally, 'it reduces the need to share the rents and spoils of government' (Ibid). In sum, high degrees of blatant electoral manipulation send a strong signal to members of the opposition that there can be no political future outside of the ruling party, and it is pointless to try and mount a challenge against the regime.

This more open and brazen form of electoral manipulation and fraud was widely practiced by the Putin regime up until the December 2011 elections when Russian citizens came out in their hundreds of thousands to protest against the results of the elections. In the more recent rounds of elections it has been largely confined to the "hegemonic authoritarian regimes" which are largely to be found in Russia's ethnic republics (see Panov and Ross, 2013).

According to Kaya and Bernhard's second perspective, "democratization by elections", elections in authoritarian regimes can turn out to be the first steps on the slippery path to democracy (2013, p. 75). As Harvey notes, elections may 'provide an opportunity for opposition groups both domestic and international to organise and mobilise against the regime, and they can also trigger mass protest, if they are perceived to have been rigged (2016, p. 106). Moreover, for Birch, 'electoral processes are the ideal background for contentious politics. They are predictably circumscribed in time, they follow well-defined, highly ritualised patterns, and they involve virtually the entire adult population' (2016, p. 14). Thus, Birch concludes, 'it is not surprising that repertoires of contentious activity should develop in many contexts where elections are viewed as being unfair' (Ibid). Clearly this was the case, following the blatant fraud in the December 2011 elections to the State Duma. A major demand of the protestors was for the annulment of the results of the election, and the sacking of the Chair of the Central Electoral Commission (see Ross, 2014).

However, just as super majoritarian victories can signal the regime's invincible power, poor results can likewise signal its weakness. As White notes, 'the 2011 election and its aftermath were hugely damaging to the Putin regime in terms of signalling and legitimation, reflected in declining approval ratings for Putin. The signal sent out to members of the political elite appeared to be that the Kremlin had lost its touch when it came to managing elections' (2017, p. 495). Even after engaging in massive and blatant fraud UR won just under half of the votes, and there was a very low turnout of just $48 \%$.

As discussed above, in the aftermath of the 2011 elections, the Russian leadership was forced to adopt a number of new strategies which have focused much more on manipulating the electoral rules in favour of United Russia, and preventing opposition candidates from standing in the elections. As Birch notes the manipulation of electoral rules, is arguably the easiest, cheapest and safest form of electoral manipulation...Domestic and international commentators may complain about 'unfair' electoral laws, but they typically refrain from deeming this form of abuse 'fraudulent' or 'illegal' (2016, p. 20). Similarly, preventing candidates from standing by declaring that their registration documentation does not conform to the legal requirements is much less risky than other forms of electoral malpractice, such as coercing or bribing voters to turn out and vote for UR, promoting "carousel voting" (multiple voting by groups of mobilised citizens), or ballot stuffing, which are more liable to weaken the regime's domestic and international legitimacy (see Birch, 2016, White, 2017).

Electoral monitors have reported that the levels of ballot rigging and other forms of electoral malpractice, whilst present in a number of regions, were far less widespread in 2017 than in previous elections, and especially those held before December 2011, when the Kremlin seemed to revel in showing off its powers to falsify the election results (see Golos, 2017a, b; Ross, 2011, 2014).

The appointment in 2016 of the liberal human rights activist, Ella Pamfilova to the post of Chair of the Central Electoral Commission has had a positive impact on some aspects of the work of the electoral commissions. However, whilst levels of fraud on Election-Day were less in 2017, than in previous elections, the level of electoral malpractice in the registration process remains high. As has been demonstrated above, large numbers of opposition candidates and party lists were denied participation in these elections.

It would thus appear that the Kremlin's new strategy has been successful. By squeezing out opposition parties at the registration stage, UR has been able to gain extra-large majorities in all of the regional assemblies and maintain very strong levels of support for its gubernatorial candidates. Moreover, it has achieved this without generating mass protests against the regime, as was the case in the aftermath of the 2011 elections to the State Duma.

However, the current policy of preventing members of the opposition from standing in the elections, has in many cases 
created lacklustre and predictable contests, and this in turn has led to a sharp decline in turnout, particularly in the gubernatorial elections. A new dilemma for the regime is how to raise turnout and maintain high levels of electoral support, without having to engage in the more blatant forms of electoral malpractice which were common before the highly contentious election to the State Duma in 2011. There is a danger that low levels of turnout may gradually erode the legitimacy of the UR, embolden the opposition, and threaten the stability of the regime.

Received: 1 November 2017 Accepted: 6 June 2018

Published online: 26 June 2018

\section{Note}

1 There were 11 regional assembly and 21 gubernatorial elections in September 2015, 39 assembly and 9 gubernatorial elections in September 2016, and 6 assembly and 16 gubernatorial elections in September 2017.

\section{References}

Bader M (2017) The role of precinct commissions in electoral manipulation: does party affiliation matter? Russ Polit 2(4):434-453. 2017

Baekken H (2015) Selections before elections: double standards in implementing election registrartion procedures in Russia? Communist Post-Communist Stud 48:61-70

Birch S (2016) The electoral tango: the evolution of electoral integrity in competitive authoritarian regimes, Max Weber Lecture No. 2016/02, European Union University, 2016. http://cadmus.eui.eu/bitstream/handle/1814/40331/ MWP_LS_2016_02.pdf;sequence=1. Accessed 12 Oct 2017

Borisov N, Korgunyuk Yu, Lyubarev A, Mikhaleva G (eds) (2015) Partiinaya Reforma i Kontrreforma 2012-2014 Godov: Predposylki, Predvaritel'nye Itogi, Tendentsii. KMK, Moscow

Davydov I (2017) Oops! How Moscow's municipal election turned into a headache for city hall. opendemocracy.net/od-russia/ivan-davydov/towards-a-different-cityopendemocracy.net, published in Johnson's Russia List, Accessed 20 Sep 2017

Donno D (2013) Elections and democratization in authoritarian regimes. Am J Political Sci 57(3):703-716

Federal Law (2002) No 67, 2002, Ob osnovnykh garantiyakh izbiratel'nykh prav i prava na uchastie $\mathrm{v}$ referendume grazhdan Rossiiskoi Federtatsii (On the Basic Guarantees of Electoral Rights and the Right to Participate in a Referendum of Citizens of the Russian Federation, as amended on 2 May 2012). Sobranie Zakonodatel'stva Rossiiskoi Federatsii, 24, item 2253. http:// pravo.gov.ru/proxy/ips/?docbody=\&nd=102076507. Accessed 4 Sep 2017

Federal Law (2014) No. 95, 2014, O vnesenii izmenenii v Federal'nyi zakon, Ob osnovnykh garantiyakh izbiratel'nykh prav i prava na uchastie v referendum grazhdan RF

Gandhi J, Lust-Okar E (2009) Elections under authoritarianism. Annu Rev Political Sci 12:403-22

Golos (2015a) Itogovoe Zayavlenie "Golosa" po Rezul'tam Obshchesbennovo Nablyudeniya za Vyborami, Naznachennymi na Edinyi Den' Golosovaniya 13 Sentyabrya 2015 goda. https://www.golosinfo.org/ru/articles/46401 Accessed 26 Oct 2017

Golos (2015b) Analytical Report No. 2. Nomination Process for Candidates and Political Party Lists Local Elections on September 13, 2015, Russian Federation. http://www.epde.org/tl_files/EPDE/EPDE\%20PRESS\%20RELEASES/ Golos_Report_2_EN_fin.pdf. Accessed 20 Mar 2017

Golos (2015c) Analiticheskii otchet No 4. Soblyudenie printsipov i standartov demokraticheskikh vyborov na stadi sbora i proberki podpisei na vyborakh, naznachennykh na 13 Sentyabrya 2015 g. http://st.golosinfo.org/2015/09/ Analytical-report-No5-ENG.pdf. Accessed 20 July 2017

Golos (2015d) Analytical Report No 5. Compliance with the Principles and Standards of Democratic Elections in the Initial Campaign Stage in the Election Scheduled for September13, 2015. http://st.golosinfo.org/2015/09/ Analytical-report-No5-ENG.pdf. Accessed 20 July 2017

Golos (2016) Parliamentary Elections 18 September 2016 Russian Federation. Registration of Political Parties And Candidates For The 2016 Election To The State Duma Of The Russian Federation. http://www.epde.org/en/ newsreader/items/parliamentary-elections-in-russia-registration-of-politicalparties-and-candidates.html. Accessed 26 Oct 2017

Golos (2017a) Statement on election monitoring results of Single Election Day on September 10, 2017. http://www.epde.org/en/newsreader/items/golos-on- september-10-russia-held-administratively-controlled-elections.html. Accessed 26 Oct 2017

Golos (2017b) Regional Elections 10 September 2017: Analytical Report on the Administrative Control over the Procedure of Collecting Signatures of Deputies of Heads of Municipal Entities in Support of Candidates ("Municipal Filter"). http://www.epde.org/tl_files/EPDE/RESSOURCES/2017\% 20Golos\%20Reports/Report_Russian_Election_Municipal_Final.pdf. Accessed 1 Oct 2017

Golosov GV (2014) Authoritarian electoral engineering and its limits: a curious case of the imperiali highest averages method in Russia. Eur-Asia Stud 66 (10):1611-28

Harvey CJ (2016) Changes in the menu of manipulation: electoral fraud, ballot stuffing, and voter pressure in the 2011 Russian election. Elect Stud 41:105-17

Hutcheson D (2017) Contextualizing the 2016 state duma election. Russian Politics 2(4):383-410

Jarabinský I (2015) Appearances are deceptive: credibility of the Russian Election Commission. East Eur Polit 31(1):88-103

Kaya R, Bernhard M (2013) Are elections mechanisms of authoritarian stability or democratization? Evidence from postcommunist Eurasia. Perspect Polit 11 (3): $734-54$

Kynev AV, Lyubarev AE, Maksimov AN (2015) Na postupakh k federal'nym vybor'nym Vyboram-2016: regioinal'nye imestnye vybory v Rossii 13 Sentyabrya 2015 goda. Liberal'naya Missiya, Moscow

Kynev AV, Lyubarev AE, Maksimov AN (2017a) Itogi vydvizheniya I Registratsii Kandidatov i partiinykh Spisok na Vyborakh Prestabitel'nykh Organov Vlasti Rossiiskikh Regionov i ikh Administrativnyikh Tsentrov, 10.09.2017. KGI, Moscow

Kynev AV, Lyubarev AE, Maksimov AN (2017b) Analiticheskii Doklad Po Monitgoringu Vyborov 10.09.2017 g. Itogovaya Konkurentsiya, Elektoral'naya Dinamika I Zakonomernosti Rezul'tatov Izbiraratel'noi Kampanii-2007. KGI, Moscow

Kynev AV, Lyubarev AE (2016) Registratsiya Kandidatov i Partiinykh Spiskov na Vyborakh. KGI, Moscow

Korgunyuk Yu, Ross C, Shpagin S (2017) Party reforms and the unbalancing of the cleavage structure in Russian regional elections, 2012-2015. Europe-Asia Studies

Litvinova D (2015, September 11) Russian regions prepare to vote after campaign of tricks, complacency, Moscow Times, p. 1

Lyubarev А (2016) Ekspert КГИ Arkadii Lyubarev Proanaliziroval Raspredelenie Mandatov na Vyborakh Regional'nykh Parlamentov, 18 September 2016 года. KGI, 17.10.2016. https://komitetgi.ru/analytics/2989/. Accessed 20 Dec 2016

Panov P, Ross C (2013) Patterns of electoral contestation in Russian regional assemblies: between competitive and hegemonic authoritarianism. Demokr: J Post-Sov Democr 21(3):369-400

Pertsev A (2017) The active minority and passive majority: takeaways from Russia's regional elections, Carnegie Moscow Centre. http://carnegie.ru/commentary/ 73171. Accessed 1 Oct 2017

Petrov N (2012, October 3) Kremlin Adopts New Strategy. The St Petersburg Times, No 1729

Popova M (2006) Watchdogs or attack dogs? The role of the Russian courts and the central election commission in the resolution of electoral disputes. Eur-Asia Stud 58(3):391-414

Ross C (2011) Regional elections and electoral authoritarianism in Russia. Eur-Asia Stud 63(4):641-662

Ross C (2014) Regional elections and electoral malpractice in Russia: the manipulation of electoral rules, voters and votes. REGION: Reg Stud Russ, East Eur, Cent Asia 3(1):147-72. 2014

Ryzhkov V (2014, September 22) United Russia wins elections but not respect. Moscow Times

Schedler A (2013) The politics of uncertainty: sustaining and subverting electoral authoritarianism. Oxford University Press, Oxford

Schulmann Ye (2017, September 18) 5 Lessons From Russia's Local Elections, Moscow Times

Schreck C (2017) Russia 'Filters' Out the Competition in Regional Elections, Radio Free Europe/Radio Liberty. https://www.rferl.org/a/russia-filters-outcompetition-regional-elections/28685869.html. Accessed 20 Sep 2017

Simpser A (2013) Why governments and parties manipulate elections: theory, practice and implications. Cambridge University Press

White D (2017) Modifying electoral authoritarianism. What the 2016 Parliamentary Elections Tell Us about the Nature and Resilience of the Putin Regime, Russian Politics 2(4):482-501

\section{Data availability}

All datasets analysed are included in the paper. 


\section{Additional information}

Competing interests: The author declares no competing interests.

Reprints and permission information is available online at http://www.nature.com/ reprints

Publisher's note: Springer Nature remains neutral with regard to jurisdictional claims in published maps and institutional affiliations.

Open Access This article is licensed under a Creative Commons Attribution 4.0 International License, which permits use, sharing, adaptation, distribution and reproduction in any medium or format, as long as you give appropriate credit to the original author(s) and the source, provide a link to the Creative Commons license, and indicate if changes were made. The images or other third party material in this article are included in the article's Creative Commons license, unless indicated otherwise in a credit line to the material. If material is not included in the article's Creative Commons license and your intended use is not permitted by statutory regulation or exceeds the permitted use, you will need to obtain permission directly from the copyright holder. To view a copy of this license, visit http://creativecommons.org/ licenses/by/4.0/.

(c) The Author(s) 2018 